\title{
Validation of the Amotivation Inventory in Physical Education: physical activity and physical self-concept
}

\author{
María Jesús Lirola $^{1}$, Christopher M. Spray ${ }^{2}$ \\ ${ }^{1}$ Universidad Miguel Hernández \\ ${ }^{2}$ Loughborough University
}

\section{Spain}

United Kingdom

Correspondencia: María Jesús Lirola. Universidad Miguel Hernández de Elche. E-mail: mlirola@umh.es

(C) Universidad de Almería and Ilustre Colegio Oficial de la Psicología de Andalucía Oriental (Spain)) 


\begin{abstract}
Introduction. According to Self-Determination Theory, it is known that motivation is an essential factor for the adherence and enjoyment of exercise, generating long-lasting habits. The importance of generating such habits from an early age is a determining factor in the future health of people. The child and youth population invests a great amount of hours per week in their training in Educational Centers. The objective of this investigation was to adapt the Amotivation Inventory-Physical Education to the Spanish context, in addition to examining its psychometric properties.
\end{abstract}

Method. Two hundred thirty-two boys and girls from 6th grade of Primary Education participated. Ages ranged from 10 to 12 years old $\left(M_{\text {age }}=10.99 ; S D=.47\right)$.

Results. The results of the confirmatory factor analysis showed adequate model fit. In addition, the factor structure was shown to be invariant by gender. High levels of internal consistency were obtained and external validity was shown through a linear regression analysis with physical activity behaviour and physical self-concept as independent variables to explain amotivation in physical education lessons.

Discussion and Conclusion. In conclusion, the scale is shown to be a reliable, genderinvariant and valid measure with both boys and girls in Primary Education.

Keywords: Motivationals factors; healthy habits; young population; body image 


\section{Resumen}

Introducción. Según la teoría de la autodeterminación, se conoce que la motivación es un factor esencial para la adherencia y el disfrute del ejercicio, generando hábitos duraderos. La importancia de generar tales hábitos desde una edad temprana es un factor determinante para la salud futura. La población infantil y juvenil invierte una gran cantidad de horas semanales en su formación en Centros Educativos. El objetivo de esta investigación fue adaptar el Inventario de desmotivación en Educación Física al contexto español, además de examinar sus propiedades psicométricas.

Método. Participaron 232 niños y niñas de $6^{\circ}$ curso de Educación Primaria. Las edades oscilaron entre los 10 y los 12 años $\left(M_{\text {edad }}=10.99 ; D T=.47\right)$.

Resultados. Los resultados del análisis factorial confirmatorio mostraron índices de ajuste adecuados. Además, se mostró su invarianza según el género. Se obtuvieron altos niveles de consistencia interna y evidencias de validez externa a través de un análisis de regresión lineal con las variables de nivel de ejercicio físico y autoconcepto físico para explicar la desmotivación en las clases de Educación Física.

Discusión y Conclusion: En conclusión, la escala se muestra como una medida fiable, invariable por género y válida para niños y niñas en la Educación Primaria.

Palabras clave: Factores motivacionales; hábitos saludables; población joven; imagen corporal 


\section{Introduction}

Based on reports from the World Health Organization (WHO, 2019) concerning the current health status of the population, it can be found that there is a progressive deterioration in general health levels over the last few decades, which predicts a decline in terms of quality of life and its length in years. There are many benefits and studies that contrast and recommend the performance of any type of physical activity as a daily habit for the improvement of current health and as a means to enjoy better future health, either at physical, psychological or social levels (Duque-Fernández, Ornelas-Contreras, \& Benavides-Pando, 2020; Ramos \& Coduras, 2020). Despite all the benefits and recommendations made by recognized institutions (i.e., WHO, 2019), the most recent scientific evidence shows that levels of exercise practice decline when children promote from primary to secondary schools, showing insufficient levels for experiencing the benefits derived from its practice (Scherrer \& Preckel, 2019; Wu, Tao, Zhang, Zhang, \& Tao, 2015). In this sense, the promotion of healthy habits (i.e., the promotion of physical activity) in this population group has become a priority.

Extensive research reflects the importance of building healthy habits from an early age, since activities performed during this stage of life seem to be more enduring over time even manifesting themselves as part of a person's daily life for the rest of their life (Hoyt, Chase-Lansdale, McDade, \& Adam, 2012; Paes, \& Bianchini, 2015). This segment of the population spends a large volume of hours in schools, thus experts in the field recommend that these centers be promoters of a holistic and integrated education, where correct health habits, such as regular exercise, are encouraged (Frantz, 2015; St Leger, \& Young, 2009). For this reason, educational centres would be a key part within the process of promoting healthy habits in children and young people, thus helping to achieve the recommendations described above. Following the timetable established in the schools of Education, we can find different subjects or disciplines among which Physical Education stands out; these classes would play a key role in the work and promotion towards adherence to exercise as a healthy habit (Gallotta et al., 2016). Specifically, Physical Education lessons can help develop healthy exercise behaviour not only at school, but also influence the decisions made by children outside school in their spare time (OFSTED, 2013). On the one hand, there are strong reasons to explore phenomena related to physical education lessons with the purpose of expanding knowledge related to the promotion and adherence to childhood physical activity in different contexts. On the 
other hand, the end of the Primary Education stage seems to be a year of great interest as it is a period of transition towards the compulsory Secondary Education stage, where changes take place in terms of interpersonal and motivational factors related to the practice of physical education (Taylor, Spray \& Pearson, 2014).

A macro-theory that has been extensively investigated in the context of Physical Education lessons and that provides light to the analysis of student's behaviours and motivation towards the practice of exercise, would be Self-Determination Theory (SDT; Deci \& Ryan, 2012; Ryan \& Deci, 2019). SDT delves into human motivation, and in particular within the context of Physical Education lessons, it has been possible to study the motivational factors that affect children in their relationship with physical activity (e.g., Ntoumanis, 2012). This theory distinguishes various level of motivation according to their degree of selfdetermination. Thus, for example, intrinsic motivation would represent the most selfdetermined type of motivation; such motivation arises when the activity is performed by the fact that it is attractive and interesting (Deci \& Ryan, 2012). In decreasing order regarding the self-determination degree, it can be found four different types of extrinsic motivation (i.e., integrated regulation, identified regulation, introjected regulation and external regulation). Finally, amotivation remains, in which the person completely lacks any type of motivation to participate in the activity and, therefore, would not maintain any type of involvement with it (Ryan \& Deci, 2019).

Relative to both intrinsic (i.e., performing an activity for the mere enjoyment of its performance) and extrinsic motivation (i.e., performing an activity as a vehicle for achieving an external goal or approval), amotivation is associated with the poorest degree of selfdetermination and involves a total absence of desire and interest in performing such behaviour (Deci and Ryan, 2002). In this line, it has been studied that people who present a lack of motivation towards a concrete activity, are not consistent in the realization of the mentioned activity, due to the lack of connection that exists between their own realization and the consequences derived from their participation (Pelletier, Fortier, Vallerand, \& Briere, 2001). Because of the lack of connection with the benefits derived from their practice, these people will invest little time and energy in its realization (Ntoumanis et al., 2004). In order to improve the understanding of this factor (i.e., amotivation) and taking into account the particularity of the educational system environment, Green-Demers et al. (2008) created and conceptually validated from a multidimensional perspective the construct of amotivation. Specifically, they 
developed four dimensions for amotivation, being: a) deficient ability beliefs, b) deficient effort beliefs, c) insufficient academic values, and d) unappealing characteristics of school tasks.

When students experience a belief in deficient ability, it may lead to amotivation when they feel that their scholastic weakness are due to poor perception of competence and when they experience reduced expectancy of self-efficacy in the completion of school tasks (Wigfield \& Eccles, 2000). Even if students are fully aware of those aspects, or tasks, that are expected of them and know how to perform them, they may feel that they do not possess the skills or abilities needed to respond and cope with the requested task (Pelletier, Dion, Tuson, $\&$ Green-Demers, 1999). In the case of amotivation, this can derive from the belief in ineffective or insufficient effort, from the absence of desire or ability to make the required effort in scholastic tasks. Children may be reticent and hesitant to engage in behaviour if it requires an investment of effort or if the requested activity or task subsequently shows no transference into their daily lives. Unattractive homework may contribute to student amotivation (Legault, Green-Demers, \& Pelletier, 2006). For their part, Ainley, Hidi and Berndorff (2002) pointed out how people need to feel a certain level of enjoyment or attraction in order for a behaviour to be performed.

Notwithstanding the existence of previous studies within SDT framework contributing to a deeper understanding of amotivation, most of them treated amotivation as a onedimensional construction. In this line, in the Spanish context, research has been conducted that has taken into account the role of amotivation either towards exercise or in physical education classes and its relationship with maladaptive psychological constructs, such as presenting lower resilience or manifesting anxious behaviours (Trigueros et al., 2019; Trigueros et al., 2020). However, based on the complexity of the educational system and school subjects and context, Shen, McCaughtry, and Martin (2008) reported that because of the particular school context and the diversity of spaces where learning takes place, these could significantly influence the type of motivation pupils could manifest. It is clear that the reasons why children may lose motivation may have different origins, conceptualizing amotivation as a single, general construct would not help to explain the scenario of low motivation levels in school settings. Legault et al. (2006) already defined amotivation within the academic context as a multifaceted variable that was attended to and dependent on multiple factors in order to become manifest. 
In accordance with the defined multidimensional concept of amotivation in education, Legault et al. (2006) generated the Academic Amotivation Inventory. The inventory was designed to examine and analyze the reasons students had for not showing interest in learning or performing their academic tasks. Using exploratory factor analysis and first- and second-order confirmatory factor analysis, the authors offered evidence for structuring academic amotivation in four factors: ability beliefs, effort beliefs, task characteristics, and task value. In addition, this four-factor structure was tested through discriminant validity and construct validity analysis with linked psychological and behavioural constructs (e.g., academic performance, self-esteem, anxiety, basic psychological needs, and subjective vitality) (Legault et al., 2006; Vlachopoulos, Katartzi, \& Kontou, 2013). This tool was developed and evaluated in the classrooms themselves. Subsequently, Shen, Winger, Li, Sun, and Rukavina, (2010a) adapted this scale to measure participation intentions in specific PE lessons.

\section{Objectives and hypotheses}

The aim of this study will be to validate to the Spanish context the scale that Shen et al. (2010) adapted to evaluate amotivation in the Physical Education discipline, as well as to show evidence of its external validity by relating the dimensions that compose amotivation with the psychological variable of positive self-concept and the frequency of physical activity. It has been shown that amotivation maintains a negative relationship with other positive psychological aspects (Baker, 2004; Pelletier et al, 2001; Vallerand et al., 1993) and that the lack of motivation leads to the inhibition of behaviour itself (Ryan \& Deci, 2019). Thus, it is hypothesized that these constructs with amotivation will show a negative relationship.

\section{Method}

\section{Participants}

A total of 232 boys and girls from 6th grade of Primary Education (130 boys and 102 girls) aged 10-12 years participated in the study $\left(M_{\text {age }}=10.99 ; S D=.47\right)$. They belonged to six different primary schools in the province of Almería (Spain).

\section{Instruments}


Amotivation. An adapted version of Shen et al. (2010) Amotivation Inventory-Physical Education (AI-PE) was applied to measure the motives of students for not wanting to take part in Physical Education (see Appendix). The AI-PE comprises 16 items distributed among the four factors proposed for amotivation: Ability beliefs (e.g., "Because I'm not good at PE"); Effort beliefs (e.g., "Because I don't have the energy to participate in PE"); Task characteristics (e.g., "Because I find that the activities being played is boring"); and Value assigned to the task (e.g., "Because participating in PE is not valuable to me"). The answers were collected on a Likert-type scale from 1 to 7, the answers corresponding to their reasons for not wanting to participate in Physical Education ( $1=$ strongly disagree; $7=$ strongly agree $)$. Previous research has supported the reliability (i.e., $\alpha$ between .85 and .91 for each dimension) and factor structure of the AI-PE subscales using confirmatory factor analysis (CFA) obtaining the following fit index: $N N F I=.99 ; C F I=.99, S R M R=.02, R M S E A=.03$ (Shen et al. 2010a).

Physical self-concept. In order to measure physical self-concept, we used the three items from the abbreviated form of the Physical Self-Description Questionnaire (Marsh, Martin, \& Jackson, 2010) and adapted to the Spanish context by Tomás, Marsh, González-Romá, Valls, and Nagengast (2014). An example of an item was "Physically, I am happy with myself" and the items were answered on a 6-point Likert scale, ranging from 1 (false) to 6 (true). Previous work has demonstrated the reliability ( $\alpha$ between .84 and .91 ) and validity (i.e., both convergent and discriminant validity) of the subscale (Marsh et al., 2010).

Level of physical activity. The Physical Activity Questionnaire for Older Children (PAQ-C; Crocker et al., 1997) adapted to the Spanish context by Manchola-González, BagurCalafat and Girabent-Farrés (2017) was used to assess the activity level of participants. The PAQ-C consists of 9 questions that evaluate different aspects of the physical activity performed by the adolescent using a 5-point Likert scale. Specifically, only the last question of the questionnaire was used to assess the level of physical activity performed during the 7 days of the week. It measured 5 overall levels, from none to vigorous physical activity. Internal consistency ( $\alpha=0.83$; Crocker et al., 1997) and validity (i.e., convergent and construct validity proved by Kowalski, Crocker \& Faulkner, 1997) have been previously demonstrated in similarly aged samples.

\section{Procedure}


The procedure for the AI-PE adaptation to Spanish was carried out using the reverse translation strategy (Muñiz, Elosua, \& Hambleton, 2013). Two independent groups formed by two translators with previous experience in the translation of psychometric tools carried out, respectively, the translation of the AI-PE from English to Spanish and again from Spanish to English. Each group was composed of a native English and a native Spanish translator. The accuracy and adequacy of the translation was judged qualitatively by consensus between the two translators based on the translations made by each one individually. In order to guarantee the proper comprehension of the items, the questionnaire was initially administered to an independent sample of children $(n=9)$. Then, six Spanish primary schools located in the same province of Almeria were consulted to request cooperation in the study. For this purpose, an initial meeting was held with the directors of the respective schools, followed by a second informative meeting with the parents/legal guardians, and informed consent was requested from the families of the participating students. In the presence of the first author of this study, the survey was conducted, who, in addition to informing about the anonymous and optional participation in the study, was at the disposal of the respondents to resolve possible doubts that may have arisen throughout the process of collecting data. Approximately 15 minutes were required to fill out the survey. This research was approved by the pertinent Bioethics Committee.

\section{Datal analysis}

First, the factor structure of the AI-PE was analysed by a confirmatory factor analysis (CFA). Observing the absence of multivariate normality (Mardia Coefficient $=412.61$; Critical Ratio=130.93), the CFA was performed using the matrix of covariances between items using the maximum likelihood method (ML) and a 2000-sample bootstrapping technique. From an empirical sampling distribution, the bootstrapping technique allows the estimation of the different parameters and their 95\% corrected bias confidence interval (Yuan \& Hayashi, 2003) along with the adjusted $p$-value obtained from the test correction $\chi 2$ (Bollen \& Stine, 1992). Previous works suggest the validity of the ML estimation method used in conjunction with the bootstrapping technique applied to ordinal variables when the response scale used contains at least five categories (Byrne, 2010; Finney \& Di Stefano, 2006).

A combination of fit indices was used to judge the model tested: $\chi 2 / \mathrm{df}, \mathrm{CFI}$ (Comparative Fit Index), IFI (Incremental Fit Index), RMSEA (Root Mean Square Error of Approximation) plus its $90 \%$ confidence interval (CI), and SRMS (Standardized Root Mean Square Re- 
sidual). Owing to the fact that the statistic $\chi 2$ is very sensitive to sample size (Jöreskog \& Sörbom, 1993) the index $\chi 2 / d f$ was used, and values below 5 were considered acceptable (Bentler, 1989). The following cut-off values were adopted: $S R M R \leq 0.08 ; C F I-I F I \geq 0.90$, and RMSEA $\leq 0.08$ (Marsh et al., 2004; Byrne, 2010; Hair et al., 2014).

To check the reliability of the instrument, an internal consistency analysis was performed in which Cronbach's alpha index $(\alpha)$ was calculated. Internal consistency values $\alpha$ $\geq .70$ were considered adequate (Fleiss, 2011; Hair et al., 2018). Subsequently, a multi-group analysis was carried out according to gender considering successive restricted models. It was estimated that the null hypothesis of invariance should be rejected in the presence of decreases > .010 CFI (Cheung \& Rensvold, 2002) or increases > .015 RMSEA (Chen, 2007) between successive restricted models. Finally, a linear regression analysis was performed in which the dependent variables considered (i.e., level of physical activity and physical self-concept) were estimated from the mean score of the four factors that compose the AI-PE. The analyses were performed using the IBM SPSS and AMOS v.22 statistical packages

\section{Results}

\section{Confirmatory factor analysis}

The CFA tested the structure of the four-factor, 16-item model (Figure 1), revealing excellent fit indexes: $\chi 2(98, N=232)=242.99, p<.001 ; \chi 2 / \mathrm{df}=2.48 ; C F I=.97 ; I F I=.97$; $R M S E A=.080(\mathrm{CI} 90 \%=.067, .093) ; S R M R=.040$. In this model, correlations between factors ranged from .27 to .60 and standardized regression weights ranged from .77 to .97, all of which were statistically significant $(p<.001)$. 


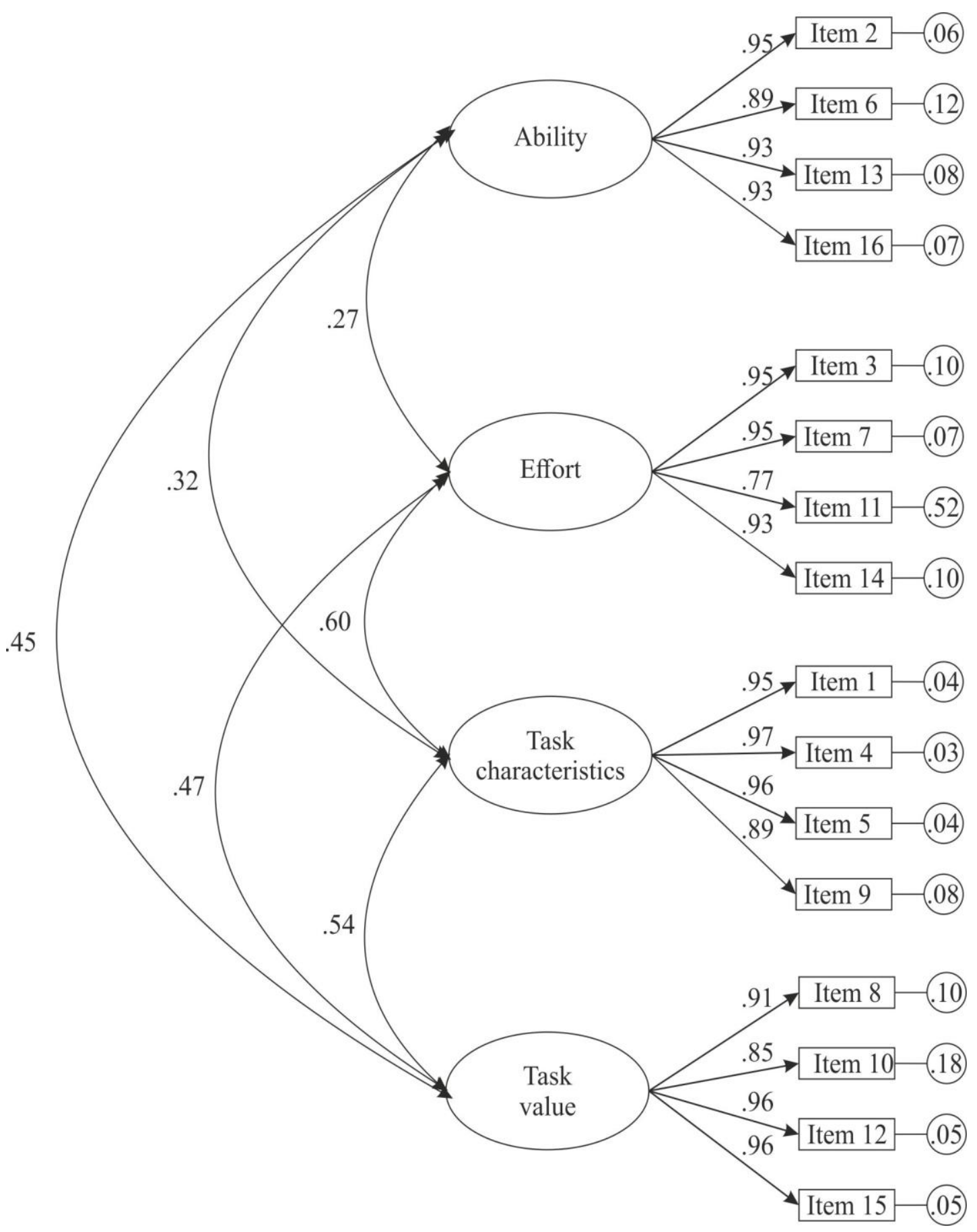

Figure 1. Confirmatory factor analysis of the four-factor model of the AI-PE.

Note: The ellipses represent the factors and the rectangles represent the items. The residual variances are shown in small circles. All correlations and regression weights shown were statistically significant $(p<.01)$

\section{Invariance analysis by gender}

Table 1 shows the adjustment indexes obtained for the structural model tested. Only significant differences (CFI increments > .01) were found between Models 3 and 4 for the 
correlated four-factor structure and there were no increments $>.015$ RMSEA between the different models. Therefore, configural, metric, and scalar invariance were accepted.

Table 1. Multigroup Gender Invariance Analysis

\begin{tabular}{|c|c|c|c|c|c|c|c|c|c|c|c|}
\hline \multicolumn{12}{|c|}{ Four-factor model of primary order } \\
\hline Model & $\chi^{2}$ & $g l$ & $\chi^{2} / d f$ & $\Delta \chi^{2}$ & $\Delta d f$ & $C F I$ & $\triangle C F I$ & $I F I$ & $\begin{array}{c}\text { RMSEA } \\
(I C 90 \%)\end{array}$ & $\triangle R M S E A$ & $S R M R$ \\
\hline Unrestricted & 477.80 & 196 & 2.44 & - & - & .94 & - & .94 & $\begin{array}{c}.079 \\
(.070-.088)\end{array}$ & - & .052 \\
\hline $\begin{array}{l}\text { Invariant } \\
\text { measurement } \\
\text { weights }\end{array}$ & 510.18 & 208 & 2.45 & $32.38 * * *$ & 12 & .94 & .00 & .94 & $\begin{array}{c}.079 \\
(.071-.088)\end{array}$ & .000 & .053 \\
\hline $\begin{array}{l}\text { Invariant } \\
\text { structural } \\
\text { weights }\end{array}$ & 598.11 & 218 & 2.74 & $120.31 * * *$ & 22 & .92 & -.02 & .92 & $\begin{array}{c}.087 \\
(.087-.102)\end{array}$ & .008 & .099 \\
\hline $\begin{array}{l}\text { Invariant } \\
\text { measurement } \\
\text { residuals }\end{array}$ & 714.01 & 234 & 3.05 & $236.21 * * *$ & 38 & .90 & -.02 & .90 & $\begin{array}{c}.094 \\
(.289-.303)\end{array}$ & .015 & .096 \\
\hline
\end{tabular}

$* * * p<.001$

Reliability analysis

Adequate levels of internal consistency were shown by the AI-PE factors as reflected in Table 2. Correlations between the different factors of AI-PE, physical self-concept and physical activity level are shown, with all correlations being significant except for the relationship between task characteristics and physical self-concept. Correlations ranged from -.30 to .60. The correlation analysis displayed values $<.80$ in its absolute term, underpinning the absence of multicollinearity among the variables inspected (Hair et al., 2018). This analysis also showed positive correlations between the four factors of amotivation. By contrast, there were negative correlations between the 4 amotivation factors and both physical activity level and physical self-concept. 
Table 2. Descriptive Statistics, Internal Consistency and Correlational Analysis between Study Variables

\begin{tabular}{|c|c|c|c|c|c|c|c|c|c|c|c|}
\hline Factors & Range & $\mathrm{M}$ & SD & $\gamma_{1}$ & $\gamma_{2}$ & $\alpha$ & 1 & 3 & 4 & 5 & 6 \\
\hline 1. Ability beliefs & $1-7$ & 1.32 & 0.70 & 2.95 & 9.38 & .96 & $.51 * * *$ & $.24 * * *$ & $.38 * * *$ & $-.35^{* * *}$ & $-.23 * * *$ \\
\hline 2. Effort beliefs & $1-7$ & 1.28 & 0.64 & 3.28 & 12.72 & .96 & - & $.37 * * *$ & $.47 * * *$ & $-.29 * * *$ & $-.28 * * *$ \\
\hline $\begin{array}{l}\text { 3. Characteristics of } \\
\text { the task }\end{array}$ & $1-7$ & 1.42 & 0.75 & 2.20 & 4.87 & .94 & & - & $.60 * * *$ & -.08 & $-.16^{*}$ \\
\hline 4. Task value & $1-7$ & 1.21 & 0.57 & 3.46 & 12.66 & .97 & & & - & $-.15^{*}$ & $-.30 * * *$ \\
\hline $\begin{array}{l}\text { 5. Physical self- } \\
\text { concept }\end{array}$ & $1-6$ & 5.27 & 1.11 & -2.11 & 4.52 & .94 & & & & - & $.31 * * *$ \\
\hline 6. Physical activity & $1-5$ & 3.53 & 0.81 & -0.36 & -0.23 & .77 & & & & & - \\
\hline
\end{tabular}

Note. $\gamma_{1}=$ Skewness; $\gamma_{2}=$ Kurtosis; $\alpha=$ Cronbach's alpha

$* p<.05 ; * * p<.01 ; * * * p<.001$

\section{Evidence of criterion validity}

Table 3 shows that of the four factors that compose amotivation, two of them predicted in a statistically significant and negative way the physical self-concept (i.e., the ability and effort beliefs) and two others did it also in the same sense for the physical activity performance (i.e., the effort belief and the task value).

Table 3. Regression Analysis Predicting Physical Self-Concept and Physical Activity Level

\begin{tabular}{|c|c|c|c|c|c|c|}
\hline \multirow[b]{2}{*}{ Independent variables } & \multicolumn{3}{|c|}{ Physical self-concept } & \multicolumn{3}{|c|}{ Physical activity } \\
\hline & $\beta$ & $t$ & $R^{2}$ & $\beta$ & $t$ & $R^{2}$ \\
\hline Ability beliefs & $-.43 * * *$ & -3.76 & .13 & -.09 & -1.10 & .11 \\
\hline Effort beliefs & $-.30 *$ & -2.21 & & $-.20 *$ & -1.99 & \\
\hline Characteristics of the task & .06 & .58 & & .06 & .72 & \\
\hline Task value & .01 & .04 & & $-.32 * *$ & -2.74 & \\
\hline
\end{tabular}

$* p<.05 ; * * p<.01 ; * * * p<.001$.

\section{Discussion and conclusion}

The aim of this investigation was to analyse the psychometric properties of AI-PE (Shen et al. 2010a) in the Spanish context. The results obtained in this study show that the AI- 
PE is a tool with adequate realiability and validity to evaluate amotivation in Physical Education lessons in Spain in line with SDT (Deci \& Ryan, 2000).

Confirmatory factor analysis supported the four-factor structure (i.e., ability beliefs, effort beliefs, characteristics of the task, and task value) proposed by Shen et al. (2010a). The resulting model was composed of four items per factor. In addition, internal consistency analyses suggest that the Spanish version of the AI-PE is a reliable measure for evaluating this construct. The multi-group analyses performed supported the existence of configurural, scalar, and metric invariance, representing for some authors a minimum requirement that would allow assuming that the instrument is invariant and, thus, comparing the means obtained in its different latent factors (Milfont \& Fischer, 2010; Strasheim, 2011).

The results of the regression analyses showed evidence of criterion validity of the AIPE by showing it to be in line with the theoretical postulates of SDT (Deci \& Ryan, 2012). From SDT, it is postulated that amotivation promotes negative results in terms of adherence to physical activity behaviour. This postulate has received empirical support in different investigations; individuals who present amotivation cannot discern a connection from what they do and the results derived from them (Pelletier, Fortier, Vallerand, \& Briere, 2001). In this sense, they will feel detached from their actions, without control over the situation and, thus, the result will be the poor investment of interest, effort or energy to perform such behaviour. In this sense, amotivation has been connected with both boredom and improper focus at school (Vallerand et al., 1993), inadequate psycho-social adjustment, a high degree of perceived stress in school (Baker, 2004) and early school dropout (Pelletier et al., 2001). On the other hand, different investigations have discovered that manifest a positive physical selfconcept may lead to a better and higher level of exercise practice behaviour (Crocker, Sabiston, Kowalski, McDonough \& Kowalski, 2006). Following Fernandez-Lasarte, Goñi, Camino and Zubeldia (2019) whose study, conducted with 1468 high school students, established a positive link between presenting a good academic self-concept and the academic performance finally obtained. Therefore, it seems that the fact of presenting high levels of self-concept in different fields or areas of life, leads the person to realize themselves more deeply within that field or subject. On the other hand, following the results obtained in the longitudinal study by Taylor et al. (2014), it can be known that when there is a decrease in physical self-concept, physical activity levels also decline. It is therefore known that there is a relationship between the student's perception of themselves and how it determines the quality of motivation mani- 
fested in the context of physical education. Hence, a negative theoretical relationship was established between the constructs of amotivation and a positive physical self-concept.

Although, in general, the results of this study provide psychometric support to the Spanish version of the AI-PE, some limitations should be taken into account. First, this instrument allows the measurement of four factors (i.e., ability beliefs, effort beliefs, characteristics of the task and task value), according to the conceptualization established by Shen et al. (2010b). Nevertheless, this multidimensional view of amotivation is currently being studied and new dimensions may emerge for its more accurate measurement. Along these lines, several authors propose the study of amotivation as a multifaceted and multidimensional construct, thus suggesting a broader framework that promotes a better understanding of the construct of amotivation with the purpose of improving strategies that encourage greater adherence to the exercise in students (Legault, Green-Demers \& Pelletier, 2006; Shen, McCaughtry \& Martin, 2008). In this way, a better and deeper understanding of this variable could result from approaching amotivation as a multi-faceted construct, and therefore favour the understanding of the variables that need to be addressed by education professionals in order to avoid amotivation in their classes and improve student participation.

Future studies should evaluate the psychometric properties of the Spanish version of the AI-PE in more age-diverse populations (e.g., first grades of Primary Education). Finally, although the validity of the construct of amotivation was shown in its levels of prediction of physical activity and physical self-concept, these are preliminary results of a first Spanish version of the AI-PE, and it must be taken into account that the development of a scale is a continuous process. Prospective research could increase the value of this construct by analyzing the effect of prediction on other specific consequences or those derived from lack of motivation (e.g., frustration of basic psychological needs, level of school absenteeism, satisfaction with exercise, oppositional defiant behaviour).

In summary, the AI-PE has proven to be a reliable and valid measuring instrument to evaluate the amotivation in Physical Education lessons in Spanish language. It is possible to measure the reasons or motives for feeling amotivation when doing Physical Education in Primary Education lessons along the lines of the definition set out by Shen et al. (2010a, 2010 b) by using this questionnaire. Therefore, this instrument can be interesting insofar as it distinguishes different variables that influence amotivation, thus being a multidimensional 
instrument that allows the establishment of links with different possible motives and a better understanding of the nature of the amotivation. This tool can be of interest to experts in the teaching of Physical Education in different centres or educational institutions.

\section{References}

Ainley, M., Hidi, S., \& Berndorff, D. (2002). Interest, learning, and the psychological processes that mediate their relationship. Journal of Educational Psychology, 94, 545-561.

Bartholomew, K. J., Ntoumanis, N., \& Thøgersen-Ntoumani, C. (2010). The controlling interpersonal style in a coaching context: development and initial validation of a psychometric scale. Journal of Sport and Exercise Psychology, 32, 193-216. https://doi.org/10.1123/jsep.32.2.193

Bentler, P. M. (1989). EQS structural equations program manual. Los Angeles, CA: BMDP Statistical Software.

Bollen, K. A., \& Stine, R. A. (1992). Bootstrapping goodness-of-fit measures in structural equation models. Sociological Methods \& Research, 21(2), 205-229. https://doi.org/10.1177/0049124192021002004

Byrne, B. M. (2010). Structural equation modeling with AMOS: Basic concepts, applications, and programming (2a Ed.). Nueva York, NY: Routledge.

Chen, F. F. (2007). Sensitivity of goodness of fit indexes to lack of measurement invariance. Structural Equation Modeling, 14(3), 464-504. https://doi.org/10.1080/10705510701301834

Cheung, G. W., \& Rensvold, R. B. (2002). Evaluating goodness-of- fit indexes for testing measurement invariance. Structural Equation Modeling, 9(2), 233-255. https://doi.org/10.1207/S15328007SEM0902

Crocker, P. R., Bailey, D. A., Faulkner, R. A., Kowalski, K. C., \& McGrath, R. (1997). Measuring general levels of physical activity: preliminary evidence for the Physical Activity Questionnaire for Older Children. Medicine \& Science in Sports \& Exercise, 29(10), 1344-1349.

Crocker, P.R.E., Sabiston, C.M., Kowalski, K.C., McDonough, M.H., \& Kowalski, N. (2006). Longitudinal assessment of the relationship between physical self-concept and healthrelated behavior and emotion in adolescent girls. Journal of Applied Sport Psychology, 18, 185-200.

Deci, E. L., \& Ryan, R. M. (2000). The "what" and "why" of goal pursuits: Human needs and the selfdetermination of behavior. Psychological Inquiry, 11, 227e268. http://dx.doi.org/10.1207/S15327965PLI1104_01

Deci, E. L., \& Ryan, R. M. (2012). Motivation, personality, and development within embedded social contexts: An overview of self-determination theory. In R. M. Ryan (Ed.), Oxford handbook of human motivation (pp. 85e107). Oxford, UK: Oxford University Press. http://dx.doi.org/10.1093/oxfordhb/9780195399820.001.0001 
Deci, E.L., \& Ryan, R.M. (2002). Overview of self-determination theory: An organismic dialectical perspective. In E.L. Deci \& R.M. Ryan (Eds.), Handbook of self-determination research (pp. 3-33). Rochester, NY: University of Rochester Press.

Duque-Fernández, L. M., Ornelas-Contreras, M., \& Benavides-Pando, E.V. (2020). Actividad física y su relación con el envejecimiento y la capacidad funcional: una revisión de la literatura de investigación. Psicología y Salud, 30(1), 45-57.

Fernández-Lasarte, O.; Goñi, E., Camino, I. y Zubeldia, M. (2019). Ajuste escolar y autoconcepto académico en la Educación Secundaria. Revista de Investigación Educativa, 37(1), 163-179. https://doi.org/10.6018/rie.37.1.308651

Finney, S. J., \& Di Stefano, C. (2006). Non-normal and categorical data in structural equation modeling. En G. R. Hancock \& R. O. Mueller (Eds.), Structural equation modeling: A second course (pp. 269-314). Greenwich, CT: Information Age.

Fleiss, J. L. (2011). Design and analysis of clinical experiments. Nueva York, NY: John Wiley \& Sons. https://doi.org/10.1002/9781118032923

Frantz, J. M. (2015). A peer-led approach to promoting health education in schools: The views of peers. South African Journal of Education, 35(1). https://doi.org/10.15700/201503070006

Gallotta, M. C., Iazzoni, S., Emerenziani, G. P., Meucci, M., Migliaccio, S., Guidetti, L., \& Baldari, C. (2016). Effects of combined physical education and nutritional programs on schoolchildren's healthy habits. PeerJ, 4, e1880. https://doi.org/10.7717/peerj.1880

Green-Demers, I., Legault, L., Pelletier, D., \& Pelletier, L.G. (2008). Factorial invariance of the academic amotivation inventory across gender and grade in a sample of Canadian high school students. Educational and Psychological Measurement, 68, 862-880.

Hair, J., Black, W., Babin, B., and Anderson, R. (2014). Multivariate Data Analysis (7th ed.). Pearson Educational, Inc.

Hair, J.F.J., Black, W.C., Babin, B.J., \& Anderson, R.E. (2018). Multivariate data analysis (8th ed.). Cengage Learning EMEA.

Hein, V., Koka, A., \& Hagger, M. S. (2015). Relationships between perceived teachers' controlling behaviour, psychological need thwarting, anger and bullying behaviour in high-school students. Journal of adolescence, 42, 103-114. https://doi.org/10.1016/j.adolescence.2015.04.003

Hoyt, L. T., Chase-Lansdale, P. L., McDade, T. W., \& Adam, E. K. (2012). Positive youth, healthy adults: does positive well-being in adolescence predict better perceived health and fewer risky health behaviors in young adulthood? Journal of Adolescent Health, 50(1), 66-73.

Jöreskog, K. G., \& Sörbom, D. (1993). LISREL 8: Structural equation modeling with the SIMPLIS command language. Chicago, IL: Scientific Software International.

Kowalski, K. C., Crocker, P. R., \& Faulkner, R. A. (1997). Validation of the physical activity questionnaire for older children. Pediatric exercise science, 9(2), 174-186. https://doi.org/10.1123/pes.9.2.174 
Legault, L., Green-Demers, I., \& Pelletier, L. G. (2006). Why do high school students lack motivation in the classroom? Toward an understanding of academic amotivation and the role of social support. Journal of Educational Psychology, 98, 567e582.

Manchola-González, J., Bagur-Calafat, C., \& Girabent-Farrés, M. (2017). Fiabilidad de la versión española del cuestionario de actividad física PAQ-C. Revista Internacional de Medicina y Ciencias de la Actividad Física del Deporte, 17(65), 139-152. http://dx.doi.org/10.15366/rimcafd2017.65.008

Marsh, H., Hau, K., and Wen, Z. (2004). In search of golden rules: comment on hypothesis testing approaches to setting cutoff values for fit indexes and dangers in overgeneralizing $\mathrm{Hu}$ and Bentler's (1999) findings. Struct. Equ. Model. 11, 320-341. http://doi.org/10.1207/s15328007sem1103-2

Marsh, H. W., Martin, A. J., \& Jackson, S. (2010). Introducing a short version of the physical self description questionnaire: new strategies, short-form evaluative criteria, and applications of factor analyses. Journal of Sport and Exercise Psychology, 32(4), 438-482. https://doi.org/10.1123/jsep.32.4.438

Milfont, T., \& Fischer, R. (2010). Testing measurement invariance across groups: Applications in cross-cultural research. International Journal of Psychological Research, 3, 111-121. https://doi.org/10.21500/20112084.857

Muñiz, J., Elosua, P., \& Hambleton, R. K. (2013). Directrices para la traducción y adaptación de los tests: Segunda edición. Psicothema, 25(2), 151-157. https://doi.org/10.7334/psicothema2013.24

Ntoumanis, N. (2012). A self-determination theory perspective on motivation in sport and physical education: Current trends and possible future research directions. In G. C. Roberts, \& D. C. Treasure (Eds.), Advances in motivation in sport and exercise: Volume 3 (pp. 91e128). Champaign, IL: Human Kinetics.

Ntoumanis, N., Pensgaard, A. M., Martin, C., \& Pipe, K. (2004). An ideographic analysis of amotivation in compulsory school physical education. Journal of Sport and Exercise Psychology, 26, $197 \mathrm{e} 214$.

Office for Standards in Education Children's Services, Skills. (2013). Beyond 2012-outstanding physical education for all: Physical education in schools. Manchester, UK.

Paes, S. T., \& Bianchini, R. M. (2015). Obesity: How can Interventions Ensure Treatment Success?. International Journal of Endocrinology \& Metabolic Disorders, 1(4). https://doi.org/10.16966/2380-548X.116

Pelletier, L. G., Fortier, M. S., Vallerand, R. J., \& Brïere, N. M. (2001). Associations between perceived autonomy support, forms of self-regulation, and persistence: A prospective study. Motivation and Emotion, 4, 279e306. 
Pelletier, L.G., Dion, S., Tuson, K., \& Green-Demers, I. (1999). Why do people fail to adopt environmentally protective behaviors? Toward a taxonomy of environmental amotivation. Journal of Applied Social Psychology, 29, 2481-2504.

Ramos, M. P. M., \& Martínez, O. C. (2020). Actividad Física y Calidad de Vida Percibida en usuarios de Centros Deportivos Públicos de Terrassa (Physical Activity and Perceived Quality of Life in users of Public Sports Centers in Terrassa). Retos, 37(37), 427-433.

Ryan, R. M., \& Deci, E. L. (2019). Brick by brick: The origins, development, and future of selfdetermination theory. In A. J. Elliot (Ed.), Advances in Motivation Science (pp. 111-162). Elsevier. https://doi.org/10.1016/bs.adms.2019.01.001

Scherrer, V., \& Preckel, F. (2019). Development of motivational variables and self-esteem during the school career: A meta-analysis of longitudinal studies. Review of Educational Research, 89(2), 211-258. https://doi.org/10.3102/0034654318819127

Shen, B., Li, W., Sun, H., \& Rukavina, P. B. (2010a). The influence of inadequate teacher-to-student social support on amotivation of physical education students. Journal of Teaching in Physical Education, 29(4), 417-432. https://doi.org/10.1123/jtpe.29.4.417

Shen, B., McCaughtry, N., \& Martin, J. (2008). The influence of domain specificity on motivation in physical education: Between and within domain relations. Research Quarterly for Exercise and Sport, 79, 333-343.

Shen, B., Wingert, R. K., Li, W., Sun, H., \& Rukavina, P. B. (2010b). An amotivation model in physical education. Journal of Teaching in Physical Education, 29(1), 72-84. DOI: https://doi.org/10.1123/jtpe.29.1.72

St Leger, L., \& Young, I. M. (2009). Creating the document 'Promoting health in schools: from evidence to action'. Global health promotion, 16(4), 69-71. https://doi.org/10.1177/1757975909348138

Strasheim, A. (2011). Testing the invariance of second-order confirmatory factor analysis models that include means and intercepts. Management Dynamics, 20(4), 38-75.

Taylor, I. M., Spray, C. M., \& Pearson, N. (2014). The influence of the physical education environment on children's well-being and physical activity across the transition from primary to secondary school. Journal of Sport and Exercise Psychology, 36(6), 574-583. https://doi.org/10.1123/jsep.2014-0038

Tomás, I., Marsh, H. W., González-Romá, V., Valls, V., \& Nagengast, B. (2014). Testing measurement invariance across Spanish and English versions of the Physical Self-Description Questionnaire: An application of exploratory structural equation modeling. Journal of Sport and Exercise Psychology, 36(2), 179-188. https://doi.org/10.1123/jsep.2013-0070

Trigueros, R., Aguilar-Parra, J. M., Álvarez, J. F., Cangas, A. J., \& López-Liria, R. (2020). The effect of motivation on the resilience and anxiety of the athlete. Revista Internacional de Medicina $y$ 
Ciencias de la Actividad Física y del Deporte, 20(77). https://doi.org/10.15366/rimcafd2020.77.005

Trigueros, R., Aguilar-Parra, J. M., Cangas, A. J., Bermejo, R., Ferrandiz, C., \& López-Liria, R. (2019). Influence of emotional intelligence, motivation and resilience on academic performance and the adoption of healthy lifestyle habits among adolescents. International journal of environmental research and public health, 16(16), 2810. https://doi.org/10.3390/ijerph16162810

Vallerand, R.J., Pelletier, L.G., Blais, M.R., Brere, N.M., Senecal, C., \& Vallieres, E.F. (1993). On the assessment of intrinsic, extrinsic, and amotivation in education: Evidence on the concurrent and construct validity of the Academic Motivation Scale. Educational and Psychological Measurement, 53, 150-172. https://doi.org/10.1177/0013164493053001018

Vlachopoulos, S. P., Katartzi, E. S., \& Kontou, M. G. (2013). Fitting multidimensional amotivation into the self-determination theory nomological network: Application in school physical education. Measurement in Physical Education and Exercise Science, 17(1), 40-61. https://doi.org/10.1080/1091367X.2013.741366

Wigfield, A., \& Eccles, J.S. (2000). Expectancy-value theory of achievement motivation. Contemporary Educational Psychology, 25, 68-81.

World Health Organization (2019). Global action plan on physical activity 2018-2030: more active people for a healthier world. World Health Organization.

Wu, X., Tao, S., Zhang, Y., Zhang, S., \& Tao, F. (2015). Low physical activity and high screen time can increase the risks of mental health problems and poor sleep quality among Chinese college students. PloS one, 10(3). https://doi.org/10.1371/journal.pone.0119607

Yuan, K.-H., \& Hayashi, K. (2003). Bootstrap approach to inference and power analysis based on three statistics for covariance structure models. The British Journal of Mathematical and Statistical Psychology, 56, 93-110. https://doi.org/10.1348/000711003321645368

Received: 04-06-2020

Accepted: 29-03-2021 


\section{Appendix}

\section{Adapted version to Spanish context of the Amotivation Inventory-Physical Education}

1. Porque para mí, E.F. no es interesante

2. Porque no soy bueno/a en E.F.

3. Porque no soy lo suficientemente enérgico para E.F.

4. Porque participar en E.F. no es importante para mí.

5. Porque participar en E.F. no es valioso para mí

6. Porque no tengo lo que se necesita para hacer bien E.F.

7. Porque soy un poco perezoso/a

8. Porque no me gusta el deporte/actividad física que se juega en E.F.

9. Porque no tengo ninguna buena razón para participar en E.F.

10. Porque el deporte/actividad que se juega es aburrido

11. Porque no me gusta tener que hacer esfuerzo para hacer E.F.

12. Porque tengo la impresión que cada día en E.F. se hace lo mismo

13. Porque no tengo el conocimiento/habilidad requerida para tener éxito en E.F.

14. Porque no tengo energía para participar en E.F.

15. Porque las actividades en E.F. no son estimulantes

16. Porque los ejercicios que me exigen en E.F. superan mi capacidad

Items composing the dimensions of the Inventory according to the structure of Shen et al., (2010): Ability beliefs: 2, 6, 13, 16; Effort belief: 3, 7, 11, 14; Value of task: 1, 4, 5, 9; Task characteristics: $8,10,12,15$. 